\title{
Mosaic trisomy 8: diagnostic approach with fetal MRI as a complement to ultrasonography
}

\author{
Ümit Aksoy Özcan', Sıla Ulus', Yasemin Alanay², Alp Dinçer', Murat Yayla \\ ${ }^{\prime}$ Department of Radiology, Faculty of Medicine Acıbadem University, Istanbul, Turkey \\ 'Department of Pediatrics, Faculty of Medicine Acıbadem University, İstanbul, Turkey \\ ${ }^{3}$ Gynecology and Obstetrics Clinic Acıbadem International Hospital, İstanbul, Turkey
}

\begin{abstract}
Objective: Trisomy 8 mosaicism (MT8) is characterized by intracranial, genitourinary and skeletal system anomalies, congenital cardiovascular disorders, deep palmar and plantar creases, and neoplastic and hematological disorders. In the literature, there are only a few antenatal ultrasound (US) and fetal magnetic resonance imaging (MRI) findings reported for MT8.

Case: The fetus whose gestational age was 26 weeks and 4 days was referred for fetal MRI due to corpus callosum agenesis suspected in routine US screening. We are presenting the major and minor MRI findings of the fetus in this case report.

Conclusion: Fetal MRI can be used in addition to the antenatal ultrasound to evaluate genetic syndromes such as trisomy 8 mosaicism and to identify additional anomalies which cannot be found in the ultrasound screening.
\end{abstract}

Keywords: Trisomy 8 mosaicism, antenatal ultrasonography, fetal magnetic resonance imaging.

\section{Introduction}

Mosaic trisomy 8 (MT8) which is also known as Warkany syndrome is a chromosomal disorder defined with the existence of three copies of chromosome 8 in some cells of organism. Its annual incidence rate varies between $1 / 25,000$ and $1 / 50,000$ and it is more common among men. ${ }^{[1-3]}$

It displays certain phenotype varieties from normal individuals up to severe malformations and they can or
Özet: Mozaik trizomi 8: Ultrasonografiyi tamamlayıcı olarak fetal MRG ile tanısal yaklaşım

Amaç: Trizomi 8 mozaizmi (MT8) intrakraniyal, genitoüriner ve iskelet sistemi anomalileri, konjenital kardiyovasküler bozukluklar, derin palmar ve plantar kıvrımlar, neoplastik ve hematolojik bozukluklarla karakterizedir. Literatürde MT8'in bildirilmiş antenatal ultrason (US) ve fetal manyetik rezonans görüntüleme (MRG) bulguları sadece birkaç tanedir.

Olgu: Gestasyonel yaşı 26 hafta 4 gün olan fetüs, rutin US taramada şüpheli korpus kallozum agenezisi nedeniyle fetal MRG için yönlendirildi. Fetüsün majör ve minör MRG bulgularını sunuyoruz.

Sonuç: Fetal MRG, trizomi 8 mozaizmi gibi genetik sendromların değerlendirilmesinde ve ultrason ile saptanamayan ek anomalilerin tespitinde antenatal ultrasona ek olarak kullanılabilir.

Anahtar sözcükler: Trizomi 8 mozaizmi, antenatal ultrasonografi, fetal manyetik rezonans görüntüleme.

cannot be seen by prenatal ultrasound (US). MT8 is characterized by intracranial, genitourinary and skeletal system anomalies, congenital cardiovascular disorders, deep palmar and plantar lines, and neoplastic and hematological disorders. The characteristics of this syndrome are shown in the Table 1. Antenatal diagnosis of this rare syndrome is very significant since it may appear with mental retardation. There are a few papers in the literature about the antenatal US findings of MT8. ${ }^{[4-6]}$
Correspondence: Dr. Sila Ulus. Acıbadem Üniversitesi Tip Fakültesi Radyoloji Anabilim Dalı, İstanbul, Turkey. e-mail: silaulus@hotmail.com Received: March 31, 2015; Kabul tarihi: May 12, 2015

Please cite this article as: Özcan ÜA, Ulus S, Alanay Y, Dinçer A, Yayla M.

Mosaic trisomy 8: diagnostic approach with fetal MRI as a complement to ultrasonography. Perinatal Journal 2015;23(2):113-115.

(C2015 Perinatal Medicine Foundation
Available online at: www.perinataljournal.com/20150232009 doi: 10.2399/prn.15.0232009 QR (Quick Response) Code

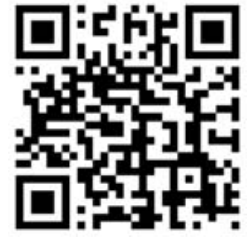


In recent years, fetal magnetic resonance imaging (MRI) has become an additional diagnostic tool for the antenatal evaluation of fetus. ${ }^{[7-9]}$ MRI evaluation of fetus requires a special approach. In addition to standard diagnostic evaluation, findings should be assessed also for a genetic syndrome. This approach may help to detect additional conditions which may be overlooked. To the best of our knowledge, there is only one study referring fetal MRI findings of MT8. In this report, we present and discuss major and minor US and MRI findings of a fetus with MT8.

\section{Case Report}

The fetus whose gestational age was 26 weeks and 4 days was referred for fetal MRI due to corpus callosum agenesis suspected in routine US screening. Also a mild ventriculomegaly and bilateral hydronephrosis were observed in the ultrasound screening. MRI was performed by using free respiration and body coil via the device with 1.5 Tesla (T) system (Magnetom Symphony, Siemens Healthcare, Erlangen, Germany). The mother was in the supine position during the examination and she was imaged by our routine fetal MRI protocol including HASTE, true FISP and two-dimensional (2D) FLASH T1-weighted sequences. In the MRI, medium level bilateral ventriculomegaly $(15 \mathrm{~mm})$ and total agenesis in the corpus callosum were observed (Fig. 1). Cranial and cerebral measurements were within normal ranges. There was no scaphocephaly, protruding forehead or micrognathia; however, lower lip was everted. Interocular ocular distance was $15 \mathrm{~mm}$ (below -2SD for week 26) and it was the indication of hypotelorism. Signal intensity of lenses was increased slightly. In addition to certain antihelixes, bigger ears and bigger lobules were observed (Fig. 1). Short and thick neck and narrow shoulders were remarked. High arched or cleft palate was not seen. There was no camptodactlia or arthrogryposis. The fetus was too small to evaluate in terms of patellar hypoplasis. Palmar or plantar lines could not be evaluated by MRI. No vertebral anomaly was detected; however, tethered cord was observed under the kidneys. There was slight bilateral hydronephrosis (anterior and posterior diameters of right and left renal pelvises were measured as 8 and $7 \mathrm{~mm}$, respectively). Stomach was dilated; however, no "double-bubble" sign was found. Fetal movement prevented to evaluate cardiac and major vascular anomalies by MRI. In the fetal echocardiography, no additional cardiac anomaly was detected. MT8 was
Table 1. Characteristics of mosaic trisomy 8.
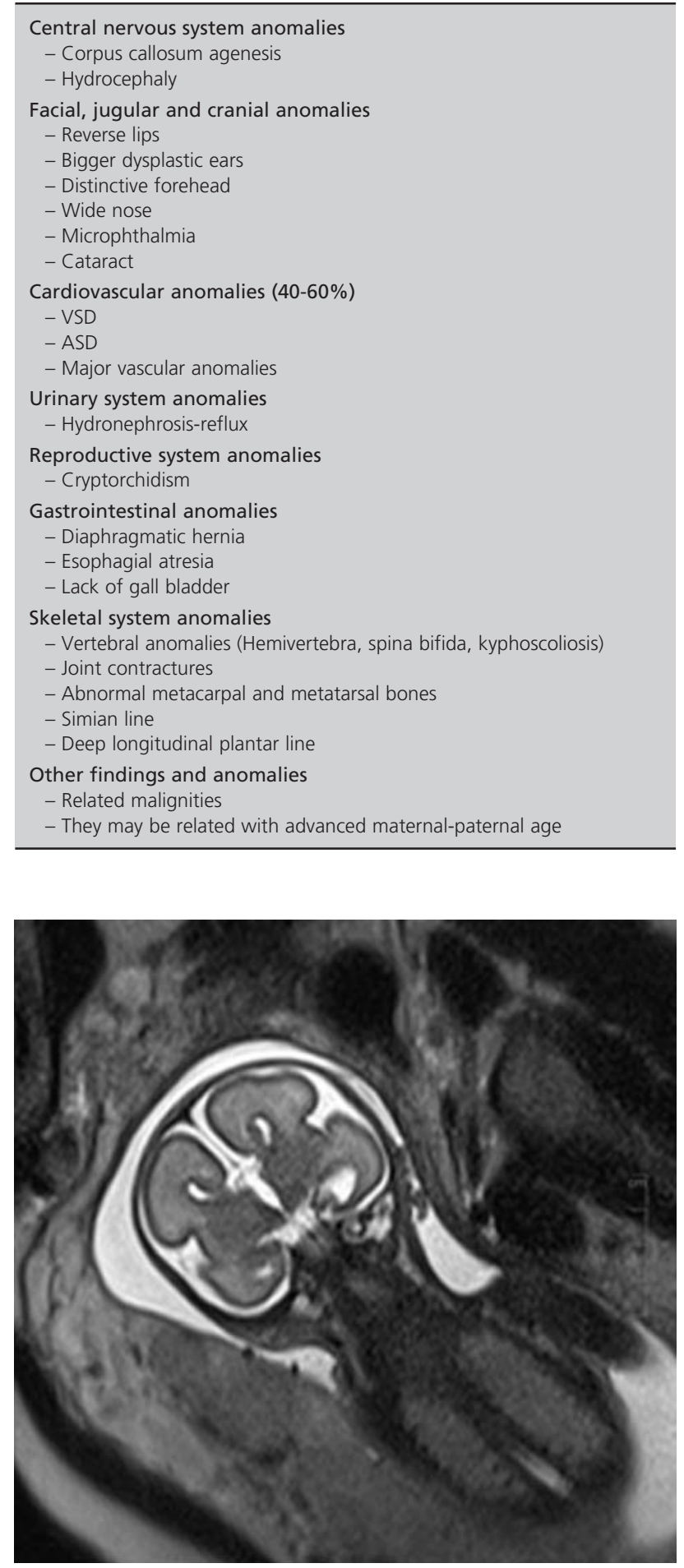

Fig. 1. In the coronal HASTE image, total agenesis of corpus callosum, distinctive antihelixes and big lobules together with bigger ears are seen. 
confirmed by the fetal blood karyotyping via cordocentesis and the patient preferred to terminate the gestation.

\section{Discussion}

Proper detection of MT8 spectrum at antenatal period and the documentation of anomalies are difficult processes requiring multidisciplinary approach since it may include multiple organ system involvement and complex anomalies. In case of clinical suspicion, final diagnosis of MT8 is established by cordocentesis. Since fetuses with MT8 are viable and they may have positive condition, detailed investigations should be carried out for the structural anomalies in the prenatal diagnosis of MT8. Early diagnosis of related anomalies may provide more information for genetic consultation and may decrease dilemmas. In the case presented in this report, we carried out cordocentesis as a result of clinical and imaging findings and established final diagnosis by genetic analysis.

Fetal MRI is a non-ionizing and non-invasive antenatal imaging method with increasing areas of use, and it presents a particular superiority over US examination for the multiplanar evaluation of complex anomalies. Using fetal MRI in our case as a modality did not only detect the suspicion of corpus callosum agenesis found in the ultrasound but also helped to identify the details requiring multiplanar analysis such as everted lower lip, hypotelorism, lens anomaly, bigger ears, short and thick neck and narrow shoulders, and tethered cord.

Fetal MRI has a higher contrast resolution compared to the ultrasound and it provides better separation of normal tissue from abnormal tissue. ${ }^{[7]}$ Fetal MRI is essentially used to confirm and characterize the anomalies found in routine prenatal ultrasound; however, it can also be used as an additional diagnostic tool to identify anomalies not observed by ultrasound and to complement ultrasound findings. Fetal MRI is useful since it can confirm the lack of callosum in suspicious corpus callosum ageneses. Fetal MRI is helpful to evaluate corpus callosum as it can be seen directly in sagittal and coronal planes after 20 weeks. Also, additional anomalies are observed together with corpus callosum agenesis and they can also be detected by fetal MRI. ${ }^{[7,8,10]}$

Gun et al. ${ }^{[5]}$ reported fetal MRI findings confirming antenatal US and corpus callosum agenesis of a fetus with MT8 which was at 23 weeks of gestation. In our case, we found and defined additional characteristics of this syndrome by MRI.
Consequently, fetal MRI can be used in addition to the antenatal ultrasound to evaluate genetic syndromes such as trisomy 8 mosaicism and to identify additional anomalies which cannot be found in the ultrasound screening.

\section{Conclusion}

Consequently, fetal MRI can be used in addition to the ante.natal ultrasound to evaluate genetic syndromes such as trisomy 8 mosaicism and to identify additional anomalies which cannot be found in the ultrasound screening.

Conflicts of Interest: No conflicts declared.

\section{References}

1. Jordan MA, Marques I, Rosendorff J, de Ravel TJ. Trisomy 8 mosaicism: a further five cases illustrating marked clinical and cytogenetic variability. Genet Couns 1998;9:139-46.

2. Wisniewska M, Mazurek M. Trisomy 8 mosaicism syndrome. J Appl Genet 2002;43:115-8.

3. Chen CP, Chen M, Pan YJ, Su YN, Chern SR, Tsai FJ, et al. Prenatal diagnosis of mosaic trisomy 8: clinical report and literature review. Taiwan J Obstet Gynecol 2011;50:331-8.

4. Campbell S, Mavrides E, Prefumo F, Presti F, Carvalho JS. Prenatal diagnosis of mosaic trisomy 8 in a fetus with normal nuchal translucency thickness and reversed end-diastolic ductus venosus flow. Ultrasound Obstet Gynecol 2001;17:341-43.

5. Gün I, Akpak YK, Müngen E. Common sonographic characteristics of trisomy 8 mosaicism. Int J Gynaecol Obstet 2012; 119:85-6.

6. Wood E, Dowey S, Saul D, Cain C, Rossiter J, Blakemore K, et al. Prenatal diagnosis of mosaic trisomy $8 \mathrm{q}$ studied by ultrasound, cytogenetics, and array-CGH. Am J Med Genet A 2008;146A:764-9.

7. Glenn OA, Barkovich AJ. Magnetic resonance imaging of the fetal brain and spine: an increasingly important tool in prenatal diagnosis, part 1. AJNR Am J Neuroradiol 2006;27:160411.

8. Glenn OA, Barkovich J. Magnetic resonance imaging of the fetal brain and spine: an increasingly important tool in prenatal diagnosis: part 2. AJNR Am J Neuroradiol 2006;27:180714.

9. Pugash D, Brugger PC, Bettelheim D, Prayer D. Prenatal ultrasound and fetal MRI: the comparative value of each modality in prenatal diagnosis. Eur J Radiol 2008;68:214-26.

10. Glenn O, Goldstein RB, Li KC, Young SJ, Norton ME, Busse $\mathrm{RF}$, et al. Fetal magnetic resonance imaging in the evaluation of fetuses referred for sonographically suspected abnormalities of the corpus callosum. J Ultrasound Med 2005;24:791-804. 